\title{
O SILÊNCIO DOS DOCENTES: UMA NOVA CONFIGURAÇÃO?
}

\section{THE SILENCE OF THE PROFESSORS: A NEW CONFIGURATION?}

LE SILENCE DES PROFESSEURS : UNE NOUVELLE CONFIGURATION?

EL SILENCIO DE LOS DOCENTES: ¿UNA NUEVA CONFIGURACIÓN?

\author{
Danilo Di Manno de Almeida *
}

\begin{abstract}
RESUMO
O presente ensaio traz uma indagação filosófica a respeito do que descreve como condiçãa existencial silenciosa do docente. Uma vez posto em questão o seu silenciamento, o autor visa encontrar os traços da configuração do silêncio docente. Quando não há mais evidências de um silenciamento ostensivo e explícito, por que ainda silenciaria o docente? Tal investigação visa examinar a desistência ética e política da palavra, analisar a dimensão efetiva da ação docente, em seu desgaste e correlativo sentimento de déficit existencial. $O$ autor procura aprofundar a hipótese de que o atual silenciamento docente tornou-se um modus vivendi, que exige de nós esforços para entender as implicaçôes institucionais e existenciais do trabalho efetivo da docência. O que poderia sugerir desencorajamento em relação às possibilidades de superar as condições efetivas da ação docente nos aponta as possibilidades de transformação das condiçôes adversas, graças mesmo ao fundo silencioso de nossa experiência e do corpo bumano.
\end{abstract}

Palavras-chave: Docência. Corpo. Silêncio. Formação. Existência. Efetividade.

* Graduação em Filosofia pela Universidade de São Paulo (1987). Mestrado em Ciências da Religião pela Universidade Metodista de São Paulo (1992). Doutorado em Filosofia pela Université de Paris X, Nanterre, França (1999). Professor titular do Mestrado em Educação da Universidade Metodista de São Paulo. Publicações principais: Pour une imagination non-européenne. Paris: Kimé, 1992; Corpo em ética: perspectivas de uma educação cidadã. São Bernardo do Campo: Edumesp: 2002 (ddmda@uol.com.br). 
A profundidade de uma experiência não está na sua duração nem na sua dramaticidade, mas no seu silêncio. A expressão da experiência e aquilo que nela se cala são duas dimensões inseparáveis. Cada experiência tem o seu silêncio. E, se podemos chegar a um acordo imediato sobre aquilo que a experiência expressa, estamos freqüentemente prontos ao desacordo sobre aquilo que está silenciado nela ou sobre aquilo que se expressa silenciosamente. Isso explica nossa dificuldade de comunicar o silêncio. Geralmente é aí que reside o conflito das opiniōes.

Essas são as idéias que este ensaio procurará desenvolver ao enfocar a atividade docente. A inquietação profunda que o anima vem de uma evidência constrangedora, sobre a qual podemos discordar e disputar: nós, docentes, tornamo-nos silenciosos. Continuamos a realizar nossas funções e a cumprir nossa tarefa de comunicação, mas temos nos calado, numa escala progressiva e comprometedora. E o pior: não se trata de um silêncio taciturno, nem de um silêncio meditativo, procurando um provável significado de nossa experiência docente. Trata-se de um silêncio de nós mesmos, de um silenciamento que se expressa naquilo que nós, profissionais das palavras e dos símbolos, fazemos.

Nós não nos calamos, simplesmente, porque passamos a utilizar novos instrumentos oferecidos pelas tecnologias. Algo mais intrigante marca a profundidade silenciosa de nossa experiência docente. Docentes e silêncio estiveram sempre enlaçados por causa do enlace silêncio/palavra. As alternativas estão dadas com clareza: exigir do docente que fale apenas o que tem de ser dito e que se cale sobre o que se interdita. Ou exigir seu silêncio absoluto. Silenciá-lo, ameaçando o seu corpo; sorrateiramente, fazer-lhe promessas e seduzi-lo ao silêncio. Num país como o Brasil, já passamos por tudo isto.

Um silenciamento está em curso. E, embora mantenha relações profundas com outros silenciamentos passados, ganha hoje novas feições. Qual a configuração do silêncio hoje, quando não é mais necessário lançar mão de ameaças contra seu corpo, quando há poucas condiçōes de fazer promessas sedutoras? Quais as características deste silêncio, quando não há gestos explícitos de silenciamento?

\section{SILENCIAMENTO}

O silenciamento é a dimensão política do silêncio (ORLANDI, p. 55). Ao aceitar essa concepção, esta dimensão nos coloca no espaço de interação, de convivência e de conflito - de sujeitos e instituições. Portanto, silenciamento não significa exclusivamente ação de um sujeito ou de uma instituição (poder de silenciar) sobre um sujeito (reduzido ao silêncio). Pois o silenciamento não é apenas coação, ele também é escolha, estratégia (LE BRETON, 1997, p. 75 e segs.). Com efeito, o silenciamento nos remete para o campo da ação - seja ela imposta/oposta pelo outro (ser silenciado) ou auto-imposta, por medo ou por estratégia (silenciar-se). Consideremos para isto as "políticas de silêncio" (LE BRETON, p. 87-111): planos secretos de revolução, o silêncio estratégico, o exílio, o ostracismo, a prisão, o mutismo, a indiferença, o indizível de uma experiência trágica. 


\section{AS (DE) CADÊNCIAS DO SILENCIAMENTO}

O silenciamento não é a "retirada" de um sujeito cansado do convívio humano. O silêncio não remete de imediato à subjetividade. Ele indica um modo subjetivo de realizar a experiência. De fato, a profundidade do silenciamento do sujeito está enraizada na sua experiência. O silêncio é o profundo de cada experiência, porque cada experiência indica a maneira como um sujeito se apropria desta experiência. Neste sentido, há vários modos de realizar a experiência do silêncio. Nós vamos visualizar três deles. Entendidos como degradês, num movimento de (de)cadência. Iremos da violência de gestos explícitos de silenciamento, passando pela mediação ostensiva da palavra, até um silenciamento atual, tão efetivo quanto o primeiro.

\section{Primeira cadência - silenciamento ostensivo}

O silêncio é uma ameaça latente às palavras de ordem. O silêncio é conspirador. O silêncio enquadra as palavras, para mostrar a sua violência, a sua força, a sua candura, a sua beleza. O silêncio é polissêmico. E, por isso, multiplica a polissemia da palavra. Mas o silêncio revela também a polissemia do corpo e de seus gestos. O silenciamento ostensivo não pode, portanto, restringir-se às palavras. É preciso que atinja o quadro das palavras e que condene as palavras ao silêncio. Mas nota-se que isto não bastará. Porque o corpo silenciosamente falará mais do que milhôes de palavras. Conclui-se que é preciso matar o lugar por excelência do silêncio, que é o corpo. Expressão absoluta de tudo, o corpo, tem que ser eliminado para que dele reste apenas a memória.

É assim que o silenciamento ostensivo passa a ser absoluto também; ele vai à raiz, à fonte. É necessário liquidar o corpo. De fato, houve uma época em que o único meio de fazer calar era assassinar o corpo. Matar o corpo para que não fique nenhum risco de silêncio.

Neste caso, o silêncio é ouro. Cumpre-se o provérbio judeu: "falar é prata, calar é ouro". Os corpos estão devotados ao silêncio, quando temem por sua sobrevivência. Mas não é o silêncio que vem do fundo da experiência livre do sujeito. É o silêncio de uma experiência violenta que se impõe sobre o silenciar da experiência de um sujeito, posto sob a violência do outro. Neste caso, o medo e o silêncio são armas de defesa. Pode até ser uma prudência exagerada, mas garante ao corpo a chance de continuar na experiência de seu silenciar. $\mathrm{O}$ corpo sabe que o silêncio não é dimensão dos mortos, mas privilégio dos vivos.

A profundidade de uma experiência não está na sua duração nem na sua dramaticidade; ela está no seu silêncio. A profundidade de uma experiência absoluta é o corpo humano. Mas eis que se descobre esse potencial do corpo e lança-se mão da extirpação do mesmo. Tempo de opressão, de censura violenta.

O quadro de silenciamento docente atual não se avizinha, nem pela memória muitas vezes, de um contexto brasileiro passado de opressão ou de censura política. Parecem estar 
suplantadas as condiçóes da década de 1960 de um "pacto de silêncio" (FAZENDA, 1988), pelo qual o educador permanecia no seu "ninho inerte, ou porque não tinha apoio ou porque tinha medo de represálias" (FAZENDA, 1988, p. 115). Que docente se reconheceria hoje nessas condições?

\section{Segunda cadência - a desistência ética e política da palavra}

Palavra e silêncio são duas dimensões da experiência humana. Elas se compõem unidas, como verso e reverso da outra. É por isso que uma experiência da palavra é uma experiência do silêncio. $\mathrm{E}$ o que aconteceu com a palavra ou com o seu encadeamento lógico, o discurso?

À medida que a violência direta contra o corpo encontra a resistência do imaginário do ética e politicamente correto, é preciso introduzir outros meios de silenciamento. Certamente, o que é ostensivo é repulsivo. A apologia da democracia política não desembocou nisto: a supremacia da palavra? O direito de falar? É como se a palavra se inscrevesse na zona do direito - e que, por aí, a violência não chocaria porque se justifica num estado de barbárie. Mas apenas neste estado. Não naquele em que o direito de falar se estabelece. Aqui, na esfera democrática da vida, até a violência contra a palavra cria a repulsa dos seus participantes. A exaltação da palavra criou a separação de dois mundos: o mundo civilizado (em que a palavra é central e seu direito conquistado) e o mundo bárbaro (que ameaça o mundo civilizado e, para o qual, a violência contra o corpo é legitimada, visto que está a serviço da preservação do mundo da palavra).

No mundo civilizado da palavra, os meios de comunicação são a via privilegiada do relacionamento humano; o debate entre discursos é o sinal de um progresso inestimado. Aqui até mesmo a violência contra a palavra é fortemente rejeitada. A redução ao silêncio é ostensiva numa sociedade da comunicação e da informação, quando se faz acompanhar da censura da palavra. A censura é repulsiva: o direito de falar é um direito adquirido, pelo menos nas sociedades politicamente democráticas (corretas). A democracia se impôs como palavra; é sinônimo do exercício do direito de se expressar... Mesmo quando o sujeito está prestes a deixar o mundo civilizado para entrar na zona da barbárie, está assegurado a ele direito de falar e de silenciar: "tudo que você disser pode ser usado contra...”). A lembrança do direito ao silêncio é a declaração de um direito e seu reverso, qual seja a ameaça velada ao corpo. É como se dissesse, "corpo, lembra-te, estás prestes a passar da esfera da palavra para a do silêncio; compreenderás como vivem simultaneamente dois mundos e duas ameaças".

A palavra passou a ocupar o lugar central. É como se tivéssemos passado de um ponto ao outro, indo da violência ao corpo à violência à palavra. Mas o corpo sabe que estamos cindidos; os dois mundos convivem. E mais gravemente ainda, estão legitimados. A violência contra o corpo não é mais generalizada, ela é legitimada numa zona de barbárie. Mas, mesmo assim, ela lança suas sombras sobre a zona democrática do direito à palavra. 
O imaginário está instruido para aceitar essa cisão. Mas o corpo sente a ameaça perene: não é necessária muita coisa para passar do lado da civilização para o lado da barbárie. Seria um retrocesso "voltar" ao silenciamento ostensivo imposto ao corpo? Não. Pois, sabe-se, hoje, que não merecerão esta condição aqueles (corpos) que ameaçarem a democracia da palavra. De fato, pressente-se, o corpo é silenciado legitimamente pela supremacia da palavra.

Assim, o que indica avanço é, concretamente, cisão legitimada de dois mundos. Mas objetará alguém: de que silenciamento falamos, então? Pois notamos a censura até nos regimes ditos democráticos! Efetivamente. Mesmo em situações de regime político democrático, não há censura até que os discursos se mostrem dissonantes e anunciem novas configurações políticas, novas idéias, novos sentimentos. E que o contrário também vale. Ou seja, que serão mantidos e indexados os discursos que revelarem capacidade de silenciar a dissonância e incitarem à continuidade da situação presente. Silenciamento é, assim, uma reação política a uma possível conspiração. O silenciamento é a providência política para um continuum.

Se a democracia exalta tanto o direito à palavra, por que dizer que estamos numa segunda "cadência"? Por duas razōes. A primeira, a referida cisão entre dois mundos, concomitantemente existentes. Coexistência de duas esferas que não causa horror generalizado, mas, ao contrário, incrementa a sua legitimação. Contudo, a razão mais forte é aquela que diz respeito ao corpo. Não adianta a palavra se impor. O silêncio está cravado no corpo. $\mathrm{O}$ silêncio como profundidade de uma experiência. Experiência profunda do corpo.

O corpo sabe que a palavra mente. Se fôssemos traduzir isso numa linguagem contemporânea, chamaríamos esse conflito entre o silêncio do corpo e a palavra democratizada de ética da palavra. O silêncio da experiência do corpo fala mais alto que as convicções despertadas pelas palavras. A memória do corpo não é memória da mente, ela se processa por outros modos. Ela não se baseia nas informações, mas nos sentidos, que são capazes de se comunicar por silêncio - pelo silêncio da paixão e da compaixão. Ainda que veja os corpos da barbárie serem legitimados pelo silêncio da palavra democrática às suas contradiçôes, sente-se corpo também. Percebe-se como membro da comunidade da palavra, mas não consegue liquidar para sempre a ameaça perene sobre todos os corpos humanos, inclusive o seu. Sente-se primeira e inevitavelmente como corpo e não a partir de sua atual condição no corpo social.

Pela sua memória, o corpo compreende o risco latente de retorno da época em que a única forma de coibição da palavra era a redução do corpo humano ao silêncio. Justamente porque o acréscimo da alternativa do uso da palavra não eliminou o risco de retorno. Eterno retorno ameaçador do silenciamento relativo do corpo-civilizado. A coexistência da barbárie do corpo e da civilização da palavra é a prova disto. 
Com efeito, o corpo civilizado acredita com descrédito na palavra. Descrédito progressivo. Compreendeu mesmo a irrelevância da palavra - e, com ela, a do silêncio. Desgaste da palavra, por vários motivos. Entre eles, por causa da ineficácia política que deram à palavra. A que concorre falar muito, pensar, ter e discutir idéias? Todas instituições da palavra permitem-lhe inferir isto. Congressos, colegiados, reuniōes, assembléias e todos os recursos da palavra para mostrar que nada acontece. Ineficácia política da palavra significou banalização do discurso, irrelevância dos discursos.

Um segundo motivo do desgaste das palavras, que está intimamente ligado ao primeiro. Quando mais fala (tanto mais cala) e por isso aprende-se mais rapidamente a ver as contradiçõos e incoerências das palavras. Disto resulta maior percepção da dissonância ética entre palavra e ações. Esse é o contragolpe da civilização da palavra: a maior exaltação da palavra gerou o seu maior descrédito. Palavras, palavras, palavras... Está incrustado na cultura ocidental. Daí por que se prega com certo sucesso a bancarrota das ideologias, o vencimento de validade das utopias. Incentiva-se o recuo para o fazer sem significação, para o sentimento da derrota. Ganha força o sentimento de uma certa irrelevância do sujeito da fala... E do sujeito do silêncio.

\section{Terceira cadência - a efetividade da sobrevivência}

O efeito dessa depreciação da palavra e do silêncio incide sobre a práxis. De fato, o sujeito se devota a um fazer, não porque o fazer é um momento de interferência naquilo que está feito - portanto, um fazer transformador da práxis. Assume primeiro lugar um fazer pelo fazer. E mais, um fazer como expressão de um silenciamento sobre o próprio fazer. A terceira cadência assume as anteriores e crava ainda mais fundo a indiferença humana num fazer decadente, numa experiência sem profundidade. Chamemos esse enraizamento superficial de efetividade.

Estamos no nível da "sublimação" decadente do silêncio. Numa de suas concepções clássicas, a sublimação implica substituição: as teclas do piano substituem o corpo da mulher, objeto de obsessão (sublimado). O que torna decadente a sublimação do silêncio é a falta de profundidade da experiência. O silêncio é substituído não porque era objeto de desejo, mas por sua irrelevância diante daquilo que o substitui, a saber, a efetividade. Assim, no lugar de interdição ou imposição do silêncio verifica-se a irrelevância efetiva da dimensão humana do silêncio.

Neste nível o silêncio é substituído de maneira rasa, porque não há mais profundidade da experiência. Há um silenciamento a respeito do silêncio - uma sobredeterminação de silêncio. Decorre daí um silenciamento sobre o corpo e sobre a palavra/silêncio. O silenciamento ostensivo imposto sobre o corpo e a ética da palavra são assumidos pelo sujeito, por meio de um silenciamento profundo. A obsessão pela efetividade torna insignificante qualquer palavra ou qualquer experiência que não tenha por finalidade a própria efetividade. 
Duas consequiências imediatas sobre o corpo e a palavra. O silêncio sobre a experiência do corpo-profundo dá lugar ao corpo-raso, corpo sem profundidade. O que conta é o corpo na efetividade: corpo-ação, corpo-efetivo ou mesmo, corpo-virtual, corpomáquina, corpo pós-humano, obsoleto (Stelarc). Por sua vez, a palavra não tem a profundidade nem teleologia. Palavra sem projeto que se exerce efetivamente como veículo, meio, instrumentalização da mídia: palavra-passagem, palavra-rasa, palavratroca, palavra-meio, sem profundidade, isto é, sem silêncio, apenas fazendo a conexão entre os pontos da efetividade.

A efetividade da sobrevivência sinaliza para uma vida que se (des)faz pelos meios, pelo fluxo das coisas, na sua exterioridade funcional ou eficiência comunicacional. Neste nível da obsessão pela efetividade da existência, tendemos a efetivar as coisas e a nos efetivar. Trabalhamos para que as coisas se realizem e para que a nossa própria realização se efetive neste nível.

\section{A EFETIVIDADE-DOCENTE E SEU SILÊNCIO}

É neste quadro que gostaria de situar o silenciamento docente atual. Depois deste longo excurso, voltemos à pergunta diretriz: quais as características de um suposto silêncio docente atual, quando não há gestos explícitos de silenciamento?

A pergunta sobre o silenciamento docente não coloca este último no centro das investigaçōes, por causa da ambigüidade desta posição. Embora seja importante celebrar o "resgate da subjetividade" docente e a sua centralidade na ação educacional, perguntome hoje se isto não serve ainda mais para dissimular um problema ${ }^{1}$ (ver meu texto de 2005). Além do mais, esta posição central serve tanto para desencadear o mea culpa de uma "consciência infeliz" (Hegel) docente, como para legitimar a difamação sistemática de destruição da imagem do docente. ${ }^{2}$ Não se trata de tirar o docente da cena, mas de situar seu silêncio num quadro maior de silenciamento. Deste modo, no centro não surge o docente, mas a situação em que ele se encontra.

O silenciamento é espaço da interação. Sujeitos e instituiçõos estão implicados. Esta implicação não aparecerá pelo tema do resgate, mas do desgaste docente - que é, a propósito, o fator de eficácia do silenciamento docente atual.

\section{CONTORNOS DE UM SILENCIAMENTO NA EFETIVIDADE}

As cadências do silenciamento devem ajudar a explicitar o pressuposto deste ensaio: a eficiência do silenciamento atual se encontra na nossa assimilação dessas cadências. A assimilação explica por que não são mais necessários gestos explícitos de silenciamento. O silêncio não se encontra mais exclusivamente sob a regência e economia do poder silenciador de outrem. 
Se não podemos ver claramente os contornos desse silenciamento, podemos ao menos arriscar a descrição de alguns de seus traços.

\section{A positivação}

$\mathrm{O}$ silenciamento não se faz por um processo de subtração. O primeiro momento (silenciamento ostensivo contra ao corpo) permanece como ameaça constante no presente. Não é simples acidente o fato de que censura ou interdições provoquem uma repulsa generalizada. Há cada vez mais uma rejeição dos processos de negação. No imaginário presente, o silêncio é tido como negação, subtração, ausência, falta, aquilo que, enfim, em nada contribui para a efetivação das experiências.

A retração, a redução, a proibição, a interdição são processos negativos. É preciso garantir a exclusividade dos processos positivos. A eficácia da positivação é muito maior. Sua aceitação pública já está preparada pelo processo dialético de assimilação progressiva de tudo. Sua concepção é ética e politicamente correta, formando um complexo conceitual respeitabilíssimo - vide o conceito de inclusão.

Se a lógica não é a da subtração, deduz-se a baixa estima (ética e política) do silêncio. Se a ordem é acrescentar, o que fazer com as experiências de subtração, redução ou negação da palavra, como o silêncio?. Ora, a coerência desta positivação é a de incluir o silêncio - mas de guardar para ele a plenitude de seu sentido de ser "silêncio", silenciando sobre ele.

\section{A efetividade do fazer}

O fazer é uma das formas mais eficazes de silenciar. Pode-se chegar até à suspensão das palavras e do próprio pensamento. Quanto mais corporal mais silencioso pode ser o fazer. Por isso mesmo, a obsessão pela efetividade atesta sobre a eficácia da cadência da efetividade. Um fazer pelo fazer, que silencia pelo fazer. Porque não há o que fazer com o silêncio no nível da efetividade. Aqui impera a positividade e as exigências da capitalização de tudo o que se faz. Razão por que o silêncio não tem efetividade no nível da positividade, se não visar um fazer efetivo. $\mathrm{O}$ silêncio que tem um fim em si mesmo desperdiça o fazer, por ser retenção, lentidão, abstração no fazer. Ele só se justifica se for devotado ao incremento da efetividade.

\section{Silêncio, efetividade e docência}

O fazer docente advém silencioso. Cada vez mais o docente fala menos. Como isso afeta a atividade docente? $\mathrm{O}$ docente não é um profissional da palavra $\mathrm{e}$ - por extensão - um profissional do silêncio? Entretanto, o silenciamento em questão não está restrito a uma circunstância tecnológica presente. Ele vai muito além da constatação do declínio da palavra direta do docente, em razão da ascensão da mídia e a conseqüente utilização de suas ferramentas. Ocorre um deslocamento contemporâneo do sujeito para os meios (media) ? ${ }^{3}$ 
O silenciamento na nossa atual (de) cadência tem um efeito muito maior, visto que o que está em questão é o silêncio sobre o silêncio na docência. Quanto a isso, o caminho percorrido até aqui deve evitar a idéia de uma vitimização do docente. E com isso a idéia de que o atual silenciamento se deve a um "pacto" ou cumplicidade do docente beneficiário dessa situação. Por outro lado, atribuir o silenciamento a uma organização ou instituição, tampouco nos faz avançar. No entanto, foi pressuposto que há um silenciamento. Designaremos esta situação de silenciamento - na qual estão imbricados sujeitos e instituições - de efetividade-docente.

Ao se silenciar sobre o profundo da experiência, o docente se silencia sobre si mesmo e sobre a sua efetividade-docente. Essa dimensão de profundidade não deveria ser confundida com a interioridade ou a intimidade do sujeito. Justamente porque ela é uma dimensão da experiência (e do sujeito como experiência). Não se trata do lugar do profundo "eu". Trata-se da dimensão profunda da experiência.

A idéia de um voluntarismo docente é tudo o que precisa ser evitado aqui. Não se trata de escolha entre ser e não ser silencioso. O silenciamento docente é constitutivo da experiência docente atual. $\mathrm{O}$ docente não advém silencioso porque reserva um tempo para refletir silenciosamente sobre o que faz. Seu silenciamento está impregnado à sua experiência de docente. Um constrangimento ao silêncio marca a docência, quando não há gestos explícitos de silenciamento.

\section{O DESGASTE DO SUJEITO DA DOCÊNCIA}

O silenciamento não será superado num "resgate" da subjetividade docente, que se voltaria para o profundo de sua experiência docente. As condições atuais da situação educacional são inexoráveis. $\mathrm{O}$ caminho fácil do voluntarismo não ajudará, não será suficiente para abordar o silenciamento docente atual. Este tem de ser enfrentado no aprofundamento do problema concreto - e efetivo - do desgaste do sujeito da docência. Duas ocasióes da efetividade-docente poderiam ajudar a esboçar este problema: a obrigação do falar docente e o sentimento docente de um déficit existencial. Por motivo de espaço, proponho que abordemos este último.

\section{EFETIVIDADE-DOCENTE}

Iniciarei este tópico com uma explicitação mais detalhada do conceito de efetividadedocente.

A efetividade-docente é um divisor de águas e um indicativo da posição docente no universo escolar ou de seu status na eficiência situacional presente. Ela dá indicações do status docente e de suas condiçõos de trabalho. É referencial para o status epistemológico, educacional (decisório e de prestígio) e econômico. Sobre as condições de trabalho aponta para o contingente-aluno, recursos pedagógicos e dificuldades/facilidades educacionais. ${ }^{4}$ 
Sem muitas especificaçôes, adentremos nesse contexto. É por meio dele que entenderemos todos os desdobramentos e implicações do silenciamento docente.

O domínio da efetividade-docente é mais ou menos intenso, doloroso, trabalhoso, à medida que se deterioram as condições de sobrevivência docente. Quanto mais o docente está próximo da efetividade-docente, mais diminui o seu status, mais aumenta o contingente-aluno. Podemos estabelecer inúmeras proporcionalidades: status econômico/ localização geográfica do trabalho; prestigio educacional/nível decisório da educação do país - mesmo que o sujeito da decisão não tenha a mínima experiência sobre o que decide. Contingente-aluno é inversamente proporcional ao status epistemológico (quanto maior a formação do docente, menos ele está afeito a grandes contingentes).

Obviamente, o quadro educacional que assegura o desenvolvimento educacional no país justificará com muita eficiência as dificuldades circunstanciais. Um senso comum expandido coloca a experiência docente no silêncio doloroso de sua efetividade.

A efetividade-docente é aquela situação em que o desgaste docente é mais expressivo. É aquela situação que está mais próxima disto que se convencionou chamar de realidade (concreta). Mais próximo deste nível estão os docentes que têm formação precária, que se deslocam para a periferia (da cidade, do país). Quanto mais estiver próximo da efetividade-docente, mais intensa será a sua difamação.

Desgaste? Docentes-executivos - perdoem-me, diante da condição proletária docente no Brasil, essa designação não deveria soar tão absurda - não se fatigam? Não sofrem também do burnout? Certamente. Mas não se trata da mesma fadiga da efetividadedocente. $\mathrm{O}$ esgotamento neste nível é insuportável, porque não tem nenhum tipo de consolação docente (monetária, prestígio, status social etc.).

Proporcionalidade intensamente inversa também é do status epistemológico e da efetividade: quanto mais o docente está próximo da zona de produção do conhecimento, mais distante está da efetividade-docente. Pela simples razão de que a efetividade não é a práxis. $\mathrm{O}$ nível da práxis pode ser comum tanto ao pesquisador (produtor do conhecimento), como ao docente-efetivo (executante do conhecimento produzido - o professor diarista). $\mathrm{O}$ docente produtor de conhecimento ensina como dar os cursos ao efetivo que dará os cursos. É a efetivação da velha distinção aristotélica entre o que sabe o que faz e o que simplesmente faz.

Do lado dos docentes que se distanciam da efetividade, a voz da eficiência epistemológica exalta o mérito da formação - nada a estranhar, já que estão em consonância com a eficiência situacional na educação. Cala-se inclusive pela irrelevância da questão salarial. Silêncio pragmático: por que levantar a questão salarial ou as condiçóes de trabalho? Para que mostrar que a hora/aula docente pode variar da média de cinco a cem reais? Não é assim no mundo dos negócios? Que tipo de franciscanismo docente levantaria essa bandeira? Segue-se a lógica da positivação e da fixação da 
condição da efetividade-docente: calar sobre aquilo que não colabora com a eficiência do sistema educacional.

A referida inexorabilidade da situação educacional ficará mais explicitada pela constituição mesma do silenciamento docente - quer o docente esteja longe ou perto da efetividade-docente. Para além das diferenças internas das classes docentes; para além dos níveis de sofrimento, extenuação, compensação, nós encontramos a constituição silenciosa da experiência docente. Tentarei mostrar que, para além desse silêncio circunstancial, há silenciamento impregnado à docência atual. Cada qual, à sua maneira, e independente do status, está destinado a um silenciamento, cujos desdobramentos deixaremos abertos à nossa imaginação.

\section{EFETIVIDADE-DOCENTE E DÉFICIT EXISTENCIAL}

Tentarei mostrar como um silenciamento pragmático produz um docente silencioso. Para que seriam necessárias técnicas de silenciamento, se o silêncio não diz mais respeito à subjetividade docente, mas à experiência docente?

$\mathrm{O}$ anonimato vence a necessidade de encontrar quem responderá pelo que se passa: $e ́$ assim. Sem paternidade, sem começo nem fim, estabelece-se um modus vivendi. $\mathrm{Na}$ altura das circunstâncias, pouco serve encontrar quem responda. A questão é prioritariamente: o que fazer com isto?

Responsabilizar o docente pela situação atual? A violência da maquinaria própria à efetividade desloca a questão. A virulência da efetividade exige que se reconheça de pronto - antes de qualquer providência epistemológica e a olhos nus - o desgaste docente. A efetividade-docente é uma máquina operacional de desgaste, em todos os aspectos, desde os mais subjetivos até os simplesmente corporais.

A atividade docente atual é constituída em consonância com a eficiência situacional da atividade docente. É essa consonância que fixa de maneira peremptória comportamentos similares e massificantes. O silêncio está nesta consonância. Como pará-la? Estamos muito além de uma explicação sobre a função docente ou sobre o anonimato institucional contemporâneo. São as aspirações mais profundas de um corpo-docente que se esvai, não num processo de formação, mas de deformação.

\section{DÉFICIT EXISTENCIAL}

De qualquer modo, todos concordarão que a formação é fundamental. Afinal, conhecimento é capital. Eis um princípio que alimenta as entranhas da positivação. Acrescentar, crescer, aumentar, desenvolver: o conhecimento e a educação. Em relação a isso, a efetividade-docente é referencial de descapitalização e corresponde à zona de pobreza da situação educacional atual. Um fosso enorme ligado por tênues pontes, que suportarão apenas um pequeno número de transeuntes, separa os dois lados: 
formação/capitalização e a efetividade-docente/zona de pobreza. Desnecessário dizer qual é o lado que se quer deixar ou evitar.

Esse sentimento de êxodo - desejado em massa, mas efetivado à medida mesma das condiçōes capitalistas de partir em retirada - é um triunfo da situação educacional. Seu êxito consiste na maneira como deixou atraente a capitalização do conhecimento. Entretanto, o que foi silenciado em tudo isto é o motor mesmo deste sentimento de capitalização do conhecimento. O que sustenta esta vontade infindável de capitalizar o conhecimento é justamente o sentimento de déficit existencial. ${ }^{5}$

Docentes encravados na zona da efetividade-docente ou situados à distância dela têm em comum o sentimento existencial de déficit. De fato, a positivação é insaciável. Como a divida externa de alguns países descapitalizados, o déficit existencial corre o risco de nunca ser liquidado.

A atividade docente atual se alimenta e é alimentada por esse sentimento deficitário. Esse sentimento é mais do que um reconhecimento de inapetência docente, que aumenta à medida da proximidade da efetividade-docente. $\mathrm{O}$ déficit existencial é muito mais profundo do que isto, visto que ele assinala o silenciamento docente e seu fazer decadente. $\mathrm{O}$ déficit surge de um sentimento de não-correspondência existencial às exigências da capitalização educacional. Trata-se da capitalização do conhecimento pela capitalização. É isto que significa a obsessão pela efetividade. O curto-circuito já foi acionado entre a existência e a efetividade. Como fazer coincidir as duas? A efetividade é infatigável, mas não porque tenha uma finalidade, além de si mesma. É o desejo obsessivo de que tudo seja efetivo. Mas a efetivação sem finalidade outra que a própria efetivação jamais se realizará, tornando-se obra pronta. Por sua vez, a existência é tida como deficitária porque ela deseja corresponder à efetividade. Porém, pelas razóes expostas, ela jamais atingirá sua finalidade.

\section{SILENCIAMENTO EFETIVO: SITUAÇÃO E PROJETO}

Um docente deficitário está sempre em silêncio, porque nunca se sente pronto para o que quer que seja. Mas não é neste ponto que veremos finalizar a tematização do silenciamento docente. Gostaria de apontar para um silenciamento em curso, quer dizer, na própria atividade docente.

Por que silenciam os docentes? Não é esta a questão investigada? O propósito era sim de mostrar um silenciamento em ato, deslocando a figura do docente para um quadro mais geral de uma situação educacional. O silenciamento docente tornou-se um modus vivendi, implicando sujeitos e instituições. Ele é constitutivo da atividade docente, que se realiza em silêncio. Em uma palavra: trata-se de um silenciamento docente na efetividade.

Como acontece o silenciamento docente na zona de pobreza da efetividade-docente? Dando a ele um projeto e uma situação. Sua situação: a sobrevivência, por causa das 
condições paupérrimas a que é submetido sendo docente. Seu projeto: afastar-se o máximo possível da efetividade-docente, superar as condições limitantes de sua atividade pela ascensão a níveis superiores da docência. Silencia-se numa luta infatigável contra o desgaste que sua atividade lhe destinou. O seu sucesso é proporcional à maneira como se sairá na efetividade. Dramática circularidade: sua saída é a própria efetividade, ou seja, o fazer efetivo. Qualquer subtração ou suspensão será evitada, por não contribuir para a consecução de sua atividade docente. Por isso a constatação terrível de que o silenciamento é constitutivo de sua atividade. Neste nível, quanto mais se evidenciar o déficit estatutário do docente, mais tentará sair dessa condição e tanto mais fincará sua existência na efetividade.

A passagem para os níveis superiores da docência é motivada pelas condições mesmas da situação educacional. Por isso, significará juntar-se aos bem-sucedidos dessa situação. Afinal, quão poucos docentes podem se dar o direito (ao luxo) de gastar seu tempo nos debates teóricos? A discussão teórica não é um oásis na atividade docente? O que poderia aumentar a freqüência nesses encontros senão a maneira determinada com que se dedicará à eficiência formativa? Não se trata de promessas, mas de posicionamento efetivo do fazer docente.

À distância da efetividade-docente, o silenciamento toma outra forma, muito embora o apego à efetividade se faça em função do mesmo sentimento de déficit existencial. $\mathrm{O}$ fosso que separa essa classe de docentes e seus congêneres mais pobres tem significado mais ideológico que econômico. O sofrimento atual da efetividade-docente projeta-se como grande horizonte para toda a categoria docente. A situação efetiva atual da educação, ao possibilitar a ideologia do distanciamento estatutário entre os docentes, pavimenta os caminhos de exploração econômica docente generalizada. Não em função de uma obra educacional em construção, mas por causa da lógica mesma da positivação e da efetividade.

Não é um fato que as lamentações começam a ecoar aqui e ali, contra o estafante trabalho a que são submetidos os docentes pós-graduados deste país? Um estudo comparativo sobre as condiçôes de trabalho dos docentes brasileiros e daqueles países que servem de aspiração educacional para os intelectuais brasileiros poderá mostrar o preço do silenciamento neste nível. Notaremos, talvez, que, comparados aos de igual qualificação alhures, os docentes-executivos brasileiros estão colados na efetividadedocente.

O silenciamento docente neste nível advém de uma semelhante pragmática da efetividade situacional: silencia-se por meio de um fazer. Fazer pelo fazer, porque não visa outra coisa que incrementar progressivamente a própria efetividade. Epistemologicamente convencido do distanciamento da efetividade-docente brasileira, restará afastarse daquilo que assombra toda docência com aspiraçôes à efetividade mundial. É preciso superar o déficit existencial de um terceiro-mundismo cultural e de um indesejável gene (tupiniquim). 
Imaginemos a situação e o projeto neste nível. A situação: um docente de excelência epistemológica atuando num local de miséria educacional. Seu projeto: afastar-se o máximo possível da miséria educacional, por meio da capitalização internacional do seu conhecimento. Silencia-se numa luta infatigável contra o desgaste da sua imagem docente. Que não haja confusões entre sua formação universal e a condição local de seu trabalho. $\mathrm{O}$ seu sucesso na efetividade é proporcional à medida que conseguir efetivar esse distanciamento por meio de uma fundamentação epistemológica, de aceitação universal. Portanto, o déficit a ser superado é aquilo que precisa ser apagado, silenciado.

\section{ROMPER OU APROFUNDAR O SILENCIAMENTO?}

O tom inexorável quase fatalista deste final não vem da elaboração deste ensaio, mas da situação de silenciamento docente. Saídas? As alternativas voluntaristas são as mais comuns, porque recorrem a uma visão moralista e processualista da situação: culpabilização dos sujeitos, responsabilização por processos e identificação das causas. Não estamos lidando com indivíduos, com categorias, com instituições, mas com uma situação efetiva. Não é o docente que se cala, mas a experiência docente que se torna silenciosa.

A lógica da positivação incentiva justamente procurar saídas efetivas para que isto se altere. É preciso, ao contrário, adentrar o silêncio de nossa experiência docente. No lugar de romper o silenciamento, aprofundá-lo. Descer fundo no silenciamento. Experimentar um silêncio estratégico, investigação, inquiridor sobre a nossa experiência docente silenciosa.

A lógica da efetividade prescreve uma sobre-determinação de silêncio. Suas investidas: tornar desprezível o silêncio, reduzir a profundidade de nossas experiências à efetividade e seus afazeres. Um silêncio estratégico remete para o corpo e suas palavras.

Quem convenceria o corpo a silenciar sobre suas experiências, a se desgastar numa ação cuja finalidade não é outra que ela mesma? Nada nem ninguém. Se um silenciamento ostensivo começa pelo corpo, da mesma forma, um aprofundamento no silêncio começa pelo corpo. Porque é um corpo amortecido e subjugado que demonstra descrédito das palavras. $\mathrm{O}$ corpo vivendo a profundidade de sua experiência não dirá palavra que não seja palavra-corpo, palavra com profundidade de sua experiência.

Esse silenciamento atual calou o nosso corpo. Afinal, por que calaria o corpo quando não houvesse nenhum gesto ostensivo de silenciamento? Ou por que falaria se não fosse obrigado? Por que se esforçaria para sair de uma situação que o destrói, se não fosse para realizar nada, mas para continuar na mesma lógica de destruição corporal?

Por que tornar desprezível o silêncio, essa subtração da efetividade? Porque o silêncio é conspirador, tanto quanto o corpo diante do silenciamento. $O$ corpo não habita idéias, mas lugares. Talvez a identificação com as idéias da efetividade tenha sido precedida de uma desistência do corpo. E o déficit existencial docente seja fundamentalmente um 
déficit de corpo. Corpo na efetividade é apenas corpo-docente, corpo-meio, corpoinstrumento da efetividade.

Provavelmente tenhamos que insistir naquilo que discordamos: sobre o nosso silêncio. Pois, sobre o que está expresso, ainda que discordemos, viremos por uma via ou outra (pela ameaça do corpo ou pelo descrédito ético e político) à efetividade. O que está sendo silenciado? Se aí reside um desacordo profundo, por causa disto mesmo, comporta possibilidades múltiplas.

O que comunica o nosso silêncio? Que o docente não tem mais o que fazer a não ser constituir-se como instrumento desta efetividade, da qual colherá migalhas para sua sobrevivência? Que ele tema que o silêncio o faça ouvir o fundo mesmo que se cala na sua atividade desesperada de falar o que os outros pensam? Quem é esse que passa a vida ensinando e que, durante todo esse tempo, limita a sua palavra e sufoca o fundo de sua experiência? Por que sua integração universal à custa do silêncio sobre o seu lugar? Que déficit existencial é este que não será jamais superado? Por que desgastará toda a sua vida em algo que, visto com um pouco mais de profundidade, jamais será alcançado?

Por que não privilegiar o descompasso, a interdição, a desconexão de sua atividade docente? Por que não percebe que sua entrega incondicional à capitalização progressiva de sua formação só se faz por causa de um sentimento incontido de um déficit existencial? Por que não interrompe tudo, ao perceber isto? Quanto de silêncio será necessário para ouvir a nossa experiência?

Se um dia concordar que cada experiência tem o seu silêncio, quantas experiências poderão vir à tona e instaurar outras docências? O quanto isto poderia alterar a situação educacional presente, sobretudo, se fosse difundida uma campanha contra a positivação da efetividade?

Talvez todas essas questões não tenham sentido para uma "raça de infatigáveis". ${ }^{6}$ Por que não perguntar, sobre o silêncio de nossa experiência? Por que não seria esta uma maneira de não ser fatalista, visto que já sabemos para onde vamos se continuarmos com as mesmas expressôes e discursos? Não sabemos, ainda, para onde iremos, se passarmos a ouvir o silêncio de nossa experiência. $\mathrm{O}$ que sabemos até agora é apenas decodificar o vetor que nos constrange todos para um mesmo lugar. Talvez não estejamos indo para nenhum lugar diferente daquele que nos extingue e nos consome o corpo, que desgasta a atividade docente e legitima a sua difamação.

No sentido que seguimos hoje, não faremos outra coisa senão nos ocuparmos da sobrevivência do corpo. E uma trágica metáfora nos lembra o fatalismo ameaçador: o mesmo esforço para garantir a sobrevivência do nosso corpo é posto para conservar a existência do corpo-docente. Quando a docência se agarra desesperadamente à efetividade, submetendo-se a todas as suas exigências, pode estar dando sinal de que encontra só ali a realização de sua função. Mas, tal como o corpo se torna progressivamente corpo-raso, 
corpo-instrumento, corpo-meio, corpo-virtual, corpo pós-humano, o docente poderá vir a ocupar essa designação num futuro não muito distante: docente-raso, docente-meio, docente-instrumento, docente-virtual, docente pós-humano.

O corpo pode estar reduzido à luta pela sua sobrevivência. Mas o corpo não é só isto. A sua sobrevivência é a condição para gozar a vida e não a única finalidade de estar aqui. $\mathrm{Na}$ docência, se levarmos em conta o fundo silencioso da nossa experiência humana, certamente sentiremos um descompasso fundamental e essencial. $\mathrm{O}$ corpo que atentasse para a profundidade silenciosa da sua experiência seria capaz de mudar as coisas. Afinal, não há outras coisas para fazer, obras a realizar? Não é preciso estar sempre destinado a participar da decadência da civilização. Quantas metáforas criadoras nasceriam, por sua vez, da junção do corpo profundo da experiência e do corpo docente em sua docência!

\section{Notas}

1. ALMEIDA, Danilo Di Manno. Subjetividade, objetividade e qualidade na pesquisa educacional: uma perspectiva filosófica. Disponível em: www.sepq.org.br/sitesipeq/index.htm (2005). Acesso em: 1 jul. 2008.

2. Idem. Subjetividade e discurso da qualidade educacional: contra a difamação docente. Revista de Educação do Cogeime. Piracicaba, v. 14, n. 26, p. 95-105, jun. 2005.

3. O que já significa um avanço na discussão sobre as relações entre o humano e a tecnologia. A situação é tão cômica que foi objeto de debate o tema do deslocamento do sujeito para os objetos (tecnológicos). Por isso, a necessidade de se chamar a atenção para a importância do sujeito na utilização dos objetos tecnológicos!!!

4. Há um limite nesta análise, que se refere explicitamente ao nível de ensino. Ela se aplica prioritariamente ao nível superior e pós-graduado, estendendo-se para a comparação entre as condiçōes de docentes destes níveis e os docentes do nível médio da educação brasileira. O nível fundamental ( $1^{\mathrm{a}}$ a $8^{\mathrm{a}}$ séries) exige algumas adaptações da análise e consideração de outros dados.

5. Por que a deficiência epistemológica assumiu a dimensão existencial - extrapolou ou recuou? é algo que merece um longo estudo. Entretanto, não vamos nos deter nisto aqui. De pronto, pode ser mencionado (a) solo comum da ideologia da capitalização da existência e do conhecimento (b) superestimação do cognitivo, outro golpe efetivo sobre o corpo.

6. Expressão de Pierre Sansot, utilizada por Denise B. de Santa’Anna (2001, p. 17).

\section{Referências}

ALMEIDA, Danilo Di Manno de Almeida. Subjetividade e discurso da qualidade educacional: contra a difamação docente. Revista de educação do Cogeime. Piracicaba. v. 14, n. 26, p. 95-105, jun. 2005 .

. Subjetividade, objetividade e qualidade na pesquisa educacional: uma perspectiva filosófica. Disponível em: <www.sepq.org.br/sitesipeq/index.htm> (2005). Acesso em: 1 jul. 2008.

ARROYO, Miguel. Oficio de mestre, imagens e auto-imagens. 6. ed. Petrópolis: Vozes, 2002. 
FAZENDA, Theresinha Rios. Educação no Brasil, anos 60: o pacto do silêncio. Rio de Janeiro: Loyola, 1988.

LE BRETON, David. Do silêncio. Lisboa: Instituto Piaget, c. 1997.

ORLANDI, Eni. As formas do silêncio; no movimento dos sentidos. 4. ed. Campinas: Edunicamp, 1997.

SANT'ANNA, Denise Bernuzzi de. Corpos de passagem; ensaios sobre a subjetividade contemporânea. São Paulo: Estação Liberdade, 2001. 


\section{The silence of the professors: a new configuration?}

\section{Abstract}

The present essay brings a philosophical interrogation with regards to what is described as a silent existential condition of the professor. The author tries to find the traces of the configuration of the silent professor. When there is no longer evidence of an ostensible and explicit silencing, why is there still silence of the professor? Such an investigation tries to examine the ethic and political renouncement of the word, analyze the effective dimension of the professor's action, in its abrasion and correlative feeling of existential deficit. The author attempts to deepen the hypothesis that the present silencing of the professor has become a modus vivendi, which requires from us efforts to understand the institutional and existential implications of the effective work of teaching. Which can suggest discouragement with respect to the possibilities of overcoming the effective conditions of the teaching work, brings out to us as possibilities of transformation of the adverse conditions, thanks to the silent background of our experience and of the human body.

Keywords: Teaching. Body. Silence. Formation. Existence. Effectiveness.

\section{Le silence des professeurs : une nouvelle configuration ?}

Résumé

Le présent article pointe à une interrogation philosophique au sujet de ce qui se décrit comme la condition silencieuse existentielle du professeur. L'auteur vise rencontrer les traits de la configuration du silence du professeur. Quand il n'y a plus d'évidences d'un silencement ostensible et explicite, pourquoi encore le professeur fait silence? Une telle investigation vise examiner le désistement éthique et politique de la parole, analyser la dimension effective de l'action du professeur, dans son usure et sentiment corrélatif de déficit existentiel. L'auteur cherche approfondir l'hypothèse que l'actuel silencement de professeur est devenu un modus vivendi, qui exige de nous des efforts pour comprendre les implications institutionnelles et existentielles du travail effectif de l'enseignement. Ce qui pourrait suggérer un découragement en relation aux possibilités de dépasser les conditions effectives de l'action d'enseignement, nous montre les possibilités de transformation des adversités, grâce au fond silencieux de notre expérience et du corps humain.

Mots clefs : Enseignement. Corps. Silence. Formation. Existence. Effectivité.

\section{El silencio de los docentes: ¿Una nueva configuración? Resumen}

El presente ensayo trae una indagación filosófica a respecto de lo que describe como condición existencial silenciosa del docente. Una vez apuntado ese silenciamento, el autor visa encontrar los trazos de la configuración del silencio docente. Cuando no hay más evidencias de un silenciamento ostensivo y explícito, ¿ Por qué aún silenciaría el docente? Tal investigación visa examinar la desistencia ética y política de la palabra, analisar la dimensión efectiva de la acción docente en su desgaste y correlativo sentimento de déficit existencial. El autor intenta profundizar la hipótesis de que el actual silenciamento docente se tornó un modus vivendi, que exige de nosotros esfuerzos para entender las implicaciones institucionales y existencias del trabajo efectivo de la docencia lo que podría sugerir desencorajamiento en relación a las posibilidades de superar condiciones efectivas de la acción docente, nos apunta las posibilidades de transformación de las condiciones adversas, gracias al fondo silencioso de nuestra experiencia y del cuerpo humano.

Palabras-clave: Docencia. Cuerpo. Silencio. Formación. Existencia. Efectividad.

Recebida I ${ }^{\mathbf{a}}$ versão em: 23.07.2008

Aceita $2^{\text {a }}$ versão em: 29.01.2009 